\title{
Protective role of Pollen Typhae total flavone against the palmitic acid-induced impairment of glucose-stimulated insulin secretion involving GPR40 signaling in INS-1 cells
}

\author{
XIAO-TAO FENG ${ }^{1-3}$, HUI-MING DUAN ${ }^{2}$ and SHUANG-LEI $\mathrm{LI}^{4}$ \\ ${ }^{1}$ Guangxi Key Laboratory of Chinese Medicine Foundation Research, ${ }^{2}$ Guangxi Scientific Experimental Center of \\ Traditional Chinese Medicine, and ${ }^{3}$ Key Laboratory for Complementary and Alternative Medicine Experimental \\ Animal Models of Guangxi, Guangxi University of Chinese Medicine, Nanning, Guangxi 530200; ${ }^{4}$ Department of Endocrinology, \\ The First Affiliated Hospital, Guangxi University of Chinese Medicine, Nanning, Guangxi 530023, P.R. China
}

Received January 31, 2017; Accepted July 5, 2017

DOI: $10.3892 / \mathrm{ijmm} .2017 .3070$

\begin{abstract}
Prolonged elevated levels of free fatty acids (FFAs) contribute to the impairment of insulin secretion function of pancreatic $\beta$ cells, a hallmark of type 2 diabetes, which is partly attributed to the dysfunction of G-protein-coupled receptor 40 (GPR40) signaling. Pollen Typhae total flavone (PTF), an extract from a Chinese herbal medicine named Pollen Typhae, has been reported to effectively treat type 2 diabetes, but the underlying mechanisms remain to be fully elucidated. In the present study, palmitic acid (PA), a saturated fatty acid, severely impaired glucose-stimulated insulin secretion (GSIS) in a timedependent manner in INS-1 cells, and PTF treatment prevented the impairment in a dose-dependent manner. Moreover, PTF improved insulin secretion function in rats presenting with type 2 diabetes induced by a high-fat diet and low-dose streptozotocin. Furthermore, PA exposure for $24 \mathrm{~h}$ decreased the protein expression of GPR40, phospholipase C (PLC) $\beta 1$, PLC $\beta 3$, and protein kinase $C$ (PKC), and inhibited the activity of PLC and PKC stimulated by GW9508, a GPR40 agonist. In addition, PTF enhanced the protein expression of GPR40 and to a certain extent strengthened the protein expression of PKC, increased cellular levels of triphosphoinositide (IP3) and diacylglycerol (DAG), and promoted GW9508-stimulated activity of PLC and PKC reduced by PA in INS-1 cells, which were blocked by PLC inhibitor U-73122 and PKC inhibitor staurosporine, respectively. Additionally, the improvement in PA-induced impairment of GSIS by PTF in INS-1 cells was restrained by U-73122, staurosporine, and calcium channel inhibitor nifedipine, respectively. The results indicate that PTF
\end{abstract}

Correspondence to: Professor Shuang-Lei Li, Department of Endocrinology, The First Affiliated Hospital, Guangxi University of Chinese Medicine, 89-9 Dongge Road, Nanning 530023, P.R. China E-mail: shuangleili@163.com

Key words: Chinese medicine, type 2 diabetes, insulin secretion, free fatty acids, G-protein-coupled receptor 40, signal transduction exerts a protective role against PA-induced impairment of GSIS involving GPR40 signaling in INS-1 cells.

\section{Introduction}

Type 2 diabetes, a chronic metabolic disorder, has become a serious public health issue worldwide. In spite of this, the prevalence of the disease still continues to increase along with changes in lifestyle and escalating obesity rates, especially in developing countries in Asia which have suffered from a rapidly emerging epidemic of diabetes (1). In addition to insulin resistance, pancreatic $\beta$ cell dysfunction, characterized by decreased insulin secretion, is another hallmark of type 2 diabetes. It is well know that type 2 diabetes often coexists with dyslipidemia, indicating elevated plasma free fatty acids (FFAs) $(2,3)$. Increased levels of FFAs not only decrease insulin-induced glucose disposal by inhibiting insulin signaling, thus leading to insulin resistance (4), but also affect insulin secretion and insulin content in pancreatic $\beta$ cells (5). Although FFAs acutely increase insulin output under physiological conditions, constitutive exposure to physiological or higher concentrations of FFAs cause detrimental effects on pancreatic $\beta$ cells. Elevated levels of FFAs induce an inflammatory response by activating Toll-like receptor-4 (TLR4)/ myeloid differentiation factor 88 (MyD88) signaling (6), trigger endoplasmic reticulum (ER) stress and apoptosis $(7,8)$, inhibit adenosine monophosphate-activated protein kinase- $\alpha$ (AMPK $\alpha$ ) (9) and insulin biosynthesis (10), thereby leading to a loss of pancreatic $\beta$ cells and a reduction in glucose-stimulated insulin secretion (GSIS) $(5,8,9)$, which cause progressive function failure of pancreatic $\beta$ cells and exacerbate type 2 diabetes. Moreover, elevated FFAs do not need to enter into the cells to exert the effects, but sustained binding occurs to the cell surface receptor called G-protein-coupled receptor 40 (GPR40), highly expressed in rodent and human pancreatic $\beta$ cells, and impairs GSIS in pancreatic $\beta$ cells (11). In fact, the gene expression of GPR40 is significantly decreased in islets from type 2 diabetic donors and chronic elevated FFA-incubated islets, which is related to reduced GSIS (11), implying dysfunction of GPR40 signaling. 
Pollen Typhae, a Chinese herbal medicine, contains flavonoids such as naringenin, kaempferol, isorhamnetin, isorhamnetin-3-O-neohesperidoside, typhaneoside, and other constituents $(12,13)$. According to previous reports, Pollen Typhae has anticoagulant activity (14) and functions to treat trauma, coronary heart diseases and myocardial infarction (15). Recently, Pollen Typhae has been used to treat type 2 diabetes in clinical practice in China. We previously reported that Pollen Typhae total flavone (PTF), an extract from Pollen Typhae mainly containing typhaneoside and other components (16), decreases blood glucose and improves insulin resistance and dyslipidemia in type 2 diabetic rats (17). Further research revealed that FFAs contribute to insulin resistance involving dysfunction of $\beta$-arrestin-2-mediated signaling (18), and that PTF has beneficial effects on this signaling, thus ameliorating insulin-induced glucose uptake and palmitic acid (PA)-induced insulin resistance $(16,19)$. The underlying molecular mechanisms of PTF in the treatment of type 2 diabetes, however, remain to be fully elucidated. Because of the action of PTF in improving dyslipidemia, we hypothesized that PTF would ameliorate FFA-induced impairment of GSIS in pancreatic $\beta$ cells.

This study aimed to observe the effects of PTF on GSIS induced by PA in INS-1 cells and to explore the potential mechanisms.

\section{Materials and methods}

Reagents. RPMI-1640 medium and fetal bovine serum (FBS) were purchased from Gibco (Grand Island, NY, USA). FFA-free bovine serum albumin (FFA-free BSA), PA, 2,3-bis(2-methoxy-4-nitro-5-sulfophenyl)-5-[(phenylamino) carbonyl]-2H-tetrazolium hydroxide (XTT), streptozotocin (STZ), sodium pyruvate, HEPES, GW9508, U-73122, nifedipine (NIF), and phenazine methosulfate (PMS) were obtained from Sigma (St. Louis, MO, USA). Culture plates were purchased from Corning (New York, NY, USA). Xi'an Salao Biotechnology Co., Ltd. (Xi'an, China) provided and confirmed PTF. The BCA protein assay kit and RIPA cell lysis buffer were from Beyotime Institute of Biotechnology Co., Ltd. (Shanghai, China). Rat insulin enzyme-linked immunosorbent assay (ELISA) kit was provided by Mercodia (Uppsala, Sweden). Rat inositol 1,4,5,-trisphosphate (IP3) ELISA kit was obtained from CusaBio (Wuhan, China). Rat diacyl glycerol (DAG) ELISA kit was purchased from Shanghai Tongwei Biological Technology Co., Ltd. (Shanghai, China). IP-One ELISA kit was obtained from Cisbio Bioassays (Codolet, France). Protein kinase C (PKC) kinase activity kit was purchased from Enzo Life Sciences (Farmingdale, NY, USA). Antibody directed against GPR40 (cat. no. sc-32905; dilution, 1:200) was purchased from Santa Cruz Biotechnology, Inc. (Santa Cruz, CA, USA). Antibodies to phospholipase C (PLC) $\beta 1$ (cat. no. ab140746; dilution, 1:1,000) and PKC (cat. no. ab23511; dilution, 1:1,000) were from Abcam (Cambridge, MA, USA). Anti-PLC $\beta 3$ antibody (cat. no. 14247; dilution, 1:1,000), secondary HRP-conjugated antibodies (cat. nos. 7074S and 7076S; dilution, 1:3,000) and staurosporine (STA) were purchased from Cell Signaling Technology (Danvers, MA, USA). ECL Plus detection reagents were provided by Hanbio Biotechnology Co., Ltd. (Shanghai, China).
Cell culture. INS-1 rat insulin-secreting cells (Shanghai Meixuan Biological Science and Technology Co., Ltd., Shanghai, China) were cultured in RPMI-1640 medium (containing $11.1 \mathrm{mM}$ glucose), supplemented with 10\% FBS, $100 \mathrm{U} / \mathrm{ml}$ penicillin, $100 \mu \mathrm{g} / \mathrm{ml}$ streptomycin, $10 \mathrm{mM}$ HEPES, $1 \mathrm{mM}$ sodium pyruvate, and $50 \mu \mathrm{M} \beta$-mercaptoethanol. The cells were maintained for growth at $37^{\circ} \mathrm{C}$ under a humidified atmosphere containing $5 \% \mathrm{CO}_{2}$. Culture medium was changed every other day.

PA preparation. $\mathrm{PA} / \mathrm{BSA}$ conjugates were prepared according to a previously described procedure (18). In brief, PA was added into $0.1 \mathrm{~N} \mathrm{NaOH}$ followed by a shaking water bath at $70^{\circ} \mathrm{C}$ until the PA was dissolved; the concentration of PA solution was $75 \mathrm{mM}$. Then, 10\% FFA-free BSA-RPMI-1640 medium was used to dilute the solution to a stock concentration of $5 \mathrm{mM}$ at $55^{\circ} \mathrm{C}$. The solution was sterilized by filtration and then kept at $-80^{\circ} \mathrm{C}$ in a refrigerator. After being placed in a water bath at $55^{\circ} \mathrm{C}$ for $15 \mathrm{~min}$, the PA solution was cooled to room temperature and diluted with 1\% FFA-free BSA-RPMI-1640 medium. The solution containing the same concentration of $\mathrm{NaOH}$ and 10\% FFA-free BSA-RPMI-1640 medium was taken as a control solution.

Viability assay. The viability was determined by XTT assay (16). Briefly, INS-1 cells were grown in 96-well culture plates. When the cells reached confluency, the cells were treated with PA $(0$ and $0.5 \mathrm{mM})$ or various concentrations of PTF $(0,0.03125,0.0625,0.125,0.25,0.5$ and $1.0 \mathrm{mg} / \mathrm{ml})$, which were diluted with $1 \%$ FFA-free BSA-RPMI-1640 medium and then added to the cells (100 $\mu \mathrm{l}$ each well). After incubation for the indicated time, $50 \mu \mathrm{l}$ of $0.10 \%$ XTT dissolved in serumfree RPMI-1640 medium was added to the cells in each well. The cells were incubated for $4 \mathrm{~h}$ at $37^{\circ} \mathrm{C}$, and then the optical absorbance was measured using a microplate reader (BioTek, Epoch; BioTek Instruments, Inc., Winooski, VT, USA) at $490 \mathrm{~nm}$.

Insulin secretion assay. Insulin secretion assay was conducted according to a previously described procedure with some modifications (20). INS-1 cells were grown in 24-well plates and reached confluency. After treatment with PA or/and PTF and inhibitors, the cells were washed with phosphate-buffered saline (PBS) twice, and incubated with Krebs-Ringer buffer (KRB: $120 \mathrm{mM} \mathrm{NaCl}, 5 \mathrm{mM} \mathrm{NaHCO} 3,5 \mathrm{mM} \mathrm{KCl}, 1.2 \mathrm{mM}$ $\mathrm{KH}_{2} \mathrm{PO}_{4}, 2.5 \mathrm{mM} \mathrm{CaCl}_{2}, 1.2 \mathrm{mM} \mathrm{MgSO}_{4}, 10 \mathrm{mM}$ HEPES, and $0.2 \% \mathrm{BSA}, \mathrm{pH} 7.2$ ) for $30 \mathrm{~min}$. Then, the cells were incubated with KRB containing 2.8 or/and $16.7 \mathrm{mM}$ glucose for $60 \mathrm{~min}$. The supernatants were collected for insulin analysis using an ELISA kit according to the manufacturer's instructions. The attached cells were lysed in cell lysis buffer followed by centrifugation to remove the debris, and the protein concentrations of the supernatants were determined using a BCA protein assay kit. Final insulin concentrations per well were normalized by the protein content.

Animal trial design. Hunan Slaccas Jingda Laboratory Animal Co., Ltd. (Changsha, China) provided male SpragueDawley rats weighing 160-200 g, and Shanghai Slaccas Laboratory Animal Co., Ltd. (Shanghai, China) provided 
chow diet: normal pellet diet (NPD) with $4.6 \%$ fat $(\sim 10 \%$ of calories as fat) and high-fat diet (HFD, 40\% of calories as fat). Type 2 diabetes was induced in the rats by a high-fat diet and low-dose STZ as previously described (17). The diabetic rats were randomly divided into 2 groups: the diabetes model group (MOD, $n=8$ ) and the PTF group (PTF, $n=8)$. The rats in the former group received an equal volume of distilled water by intragastric administration per day and free access to HFD, while the rats in the latter group were administered PTF $(0.20 \mathrm{~g} / \mathrm{kg} /$ day) by oral gavage each day and received HFD freely. The NPD-fed rats were taken as a control group $(\mathrm{CON}$, $\mathrm{n}=8$, non-diabetic rats) receiving an equal volume of distilled water by intragastric administration each day and NPD feeding. The treatment course lasted for 4 weeks. Blood was collected before and after treatment, and insulin secretion function of pancreatic $\beta$ cells was evaluated by Homeostasis model assessment of $\beta$ cell function (HOMA- $\beta$ ). HOMA- $\beta=20 \mathrm{x}$ fasting insulin/(fasting glucose - 3.5) (21). This study was approved by the Ethics Committee of Guangxi University of Chinese Medicine. All procedures were in accordance with internationally accepted principles for laboratory animal use and care.

Determination of IP3 and DAG. After treatment with PA or/and PTF and U-73122 for $24 \mathrm{~h}$, the cells were incubated with KRB containing $2.5 \mathrm{mM}$ glucose for $1 \mathrm{~h}$ followed by treatment with $16.7 \mathrm{mM}$ glucose for $5 \mathrm{~min}$. Then, the cells were collected and stored overnight at $-20^{\circ} \mathrm{C}$. After two freeze-thaw cycles to break up the cell membranes, the cell lysates were centrifuged $\left(5,000 \times \mathrm{g}, 4^{\circ} \mathrm{C}, 5 \mathrm{~min}\right.$ for IP3; $1900 \mathrm{x} \mathrm{g}, 4^{\circ} \mathrm{C}, 20 \mathrm{~min}$ for $\mathrm{DAG})$ to remove the debris. The supernatants were used to analyze IP3 and DAG levels using ELISA kits according to the manufacturer's instructions. The final concentrations of IP3 and DAG were normalized by the protein content, respectively.

PLC activity assay. IP-One ELISA kit was used to analyze the activity of PLC by quantification of inositol phosphate (IP1) according to the manufacturer's instructions. The cells were preincubated with PA or/and PTF and U-73122 for $24 \mathrm{~h}$. The cells were then exposed to GW9508 $(20 \mu \mathrm{M})$. After stimulation for $60 \mathrm{~min}$, the cells were lysed and centrifuged. The supernatants were transferred to the ELISA plate followed by an addition of IP1-HRP conjugate and anti-IP1 monoclonal antibodies. After incubation for $3 \mathrm{~h}$ at room temperature, the plate was washed and TMB was added and incubation was carried out for $30 \mathrm{~min}$ at room temperature in a dark environment. Finally, stop solution was added to the plate to stop the reaction and the optical absorbance was read at $450 \mathrm{~nm}$ with optical correction at $620 \mathrm{~nm}$ using a microplate reader (Infinite ${ }^{\circledR} 200$ Pro NanoQuant; Tecan, Männedorf, Switzerland). The concentration of IP1 was calculated according to the standard curve and normalized by the protein content.

Determination of PKC activity. The activity of PKC was determined using a commercial ELISA kit. The cells were preincubated with PA or/and PTF and STA for $24 \mathrm{~h}$. The cells were then stimulated with or without GW9508 $(20 \mu \mathrm{M})$ for $60 \mathrm{~min}$. After cell lysis and subsequent centrifugation, the supernatants of cell lysates were transferred to the ELISA plate for determination of PKC activity according to the manufacturer's instructions. Finally, the plate was read at $450 \mathrm{~nm}$ using a microplate reader (Infinite ${ }^{\circledR} 200$ Pro NanoQuant; Tecan). The PKC activity was normalized by the protein content.

Western blotting. The protein expression in INS-1 cells was analyzed by western blotting as previously described with certain modifications (16). After treatment for $24 \mathrm{~h}$, the cells were washed twice with ice-cold PBS, and then lysed in RIPA cell lysis buffer for $15 \mathrm{~min}$ on ice. The lysates were centrifugated $\left(12,000 \mathrm{x} \mathrm{g}\right.$ for $\left.5 \mathrm{~min}, 4^{\circ} \mathrm{C}\right)$ to remove the insoluble material. The supernatants were collected and then the protein concentrations were determined by the BCA method. The proteins were subjected to sodium dodecyl sulfate-polyacrylamide gel electrophoresis (SDS-PAGE) and then electrophoretically transferred to polyvinylidene difluoride membranes. The membranes were incubated with the appropriate primary antibodies overnight at $4^{\circ} \mathrm{C}$ and then with the HRP-conjugated secondary antibodies for $1 \mathrm{~h}$ at room temperature. Immunoreactivity was visualized by incubation with ECL reagents.

Statistical analysis. The data are presented as the means \pm standard deviation (SD). Student's t-test was used to identify the significant differences between two groups. When multiple comparisons were performed, the significance was analyzed by one-way analysis of variance (ANOVA). All data were analyzed with SPSS 16.0 for Windows. A value of $\mathrm{P}<0.05$ was regarded as statistically significant.

\section{Results}

PA impairs GSIS in INS-1 cells. As shown in Fig. 1, exposure to $0.5 \mathrm{mM}$ PA of the INS-1 cells for 8,16 and $24 \mathrm{~h}$ significantly impaired the viability (all $\mathrm{P}<0.01$ ) (Fig. 1A) as compared to the control (0.0 mM PA), respectively, but the insulin secretion in response to $2.8 \mathrm{mM}$ glucose (basic insulin secretion) was not markedly changed by PA (Fig. 1B). In the presence of high glucose $(16.7 \mathrm{mM})$ stimulation, PA pretreatment for $8 \mathrm{~h}$ only reduced GSIS by $3.54 \%$ without statistical significance when compared to the control ( $\mathrm{P}>0.05$ ) (Fig. 1C), but administration of PA for 16 and $24 \mathrm{~h}$ obviously decreased GSIS by $16.65 \%$ $(\mathrm{P}<0.05)$ (Fig. 1C) and 27.61\% ( $\mathrm{P}<0.01)$ (Fig. 1C), respectively. The data indicate that PA impairs GSIS in a time-dependent manner in INS-1 cells.

PTF prevents the impairment of GSIS induced by PA in INS-1 cells. As shown in Fig. 2, treatment with PA $(0.5 \mathrm{mM})$ for 16 (Fig. 2A) and $24 \mathrm{~h}$ (Fig. 2B) markedly reduced GSIS in INS-1 cells, respectively. Moreover, administration of PTF for $16 \mathrm{~h}$ at the concentrations of 0.25 and $0.5 \mathrm{mg} / \mathrm{ml}$ significantly prevented the reduction in GSIS induced by PA (all $\mathrm{P}<0.01$ ). Moreover, PA-induced impairment of GSIS was also blocked by PTF treatment for $24 \mathrm{~h}$ at all concentrations $(0.125,0.25$ and $0.5 \mathrm{mg} / \mathrm{ml}$, all $\mathrm{P}<0.01)$. Notably, the improvement by PTF was dependent on the dose of PTF, meaning that PTF dose dependently potentiated GSIS induced by PA in the INS-1 cells. Additionally, treatment with PTF for $24 \mathrm{~h}$ at the concentration of $0.5 \mathrm{mg} / \mathrm{ml}$ also increased GSIS (P<0.01) (Fig. 3A) in the absence of PA when compared to the control $(0.0 \mathrm{mg} /$ $\mathrm{ml}$ PTF). In addition, PTF at the concentrations of 0.03125 $1.0 \mathrm{mg} / \mathrm{ml} \mathrm{did}$ not obviously affect the viability of the INS-1 cells (Fig. 3B). The results suggest that PTF prevents 

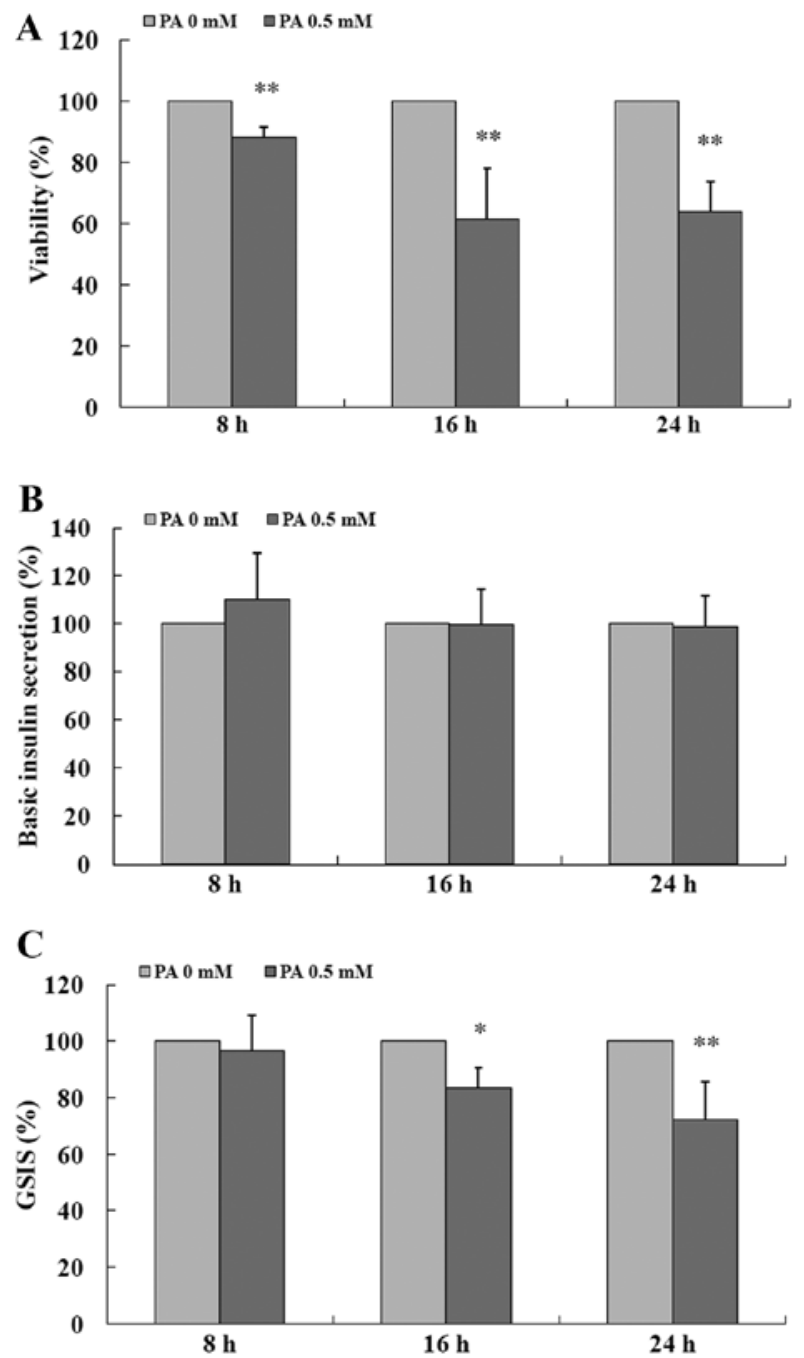

Figure 1. Effects of palmitic acid (PA) on the viability and insulin secretion in INS-1 cells. After treatment with PA for 8, 16 and $24 \mathrm{~h}$, respectively, the cells were analyzed for viability by XTT assay (A), or stimulated with 2.8 [(B) basic insulin secretion] and $16.7 \mathrm{mM}$ glucose [(C) glucose-stimulated insulin secretion (GSIS)], and insulin secretion was assessed as described in Materials and methods. ${ }^{~} \mathrm{P}<0.05$ and ${ }^{* * *} \mathrm{P}<0.01$ vs. the control $(0.0 \mathrm{mM} \mathrm{PA})$. $\mathrm{n}=4-6$.

PA-induced impairment of GSIS in a dose-dependent manner in INS-1 cells.

PTF ameliorates the insulin secretion function in type 2 diabetic rats. To further confirm the effects of PTF on insulin secretion in vivo, type 2 diabetes was induced in rats by a highfat diet and low-dose STZ. We previously reported that type 2 diabetic rats are characterized by hyperglycaemia, insulin resistance, and dyslipidemia (17). In this study, the insulin secretion function of pancreatic $\beta$ cells was severely impaired in type 2 diabetic rats, showing much lower HOMA- $\beta$ than that in the control group $(\mathrm{P}<0.01)$ (Fig. 4). Administration of PTF for 4 weeks significantly inhibited a further reduction in HOMA- $\beta$ in the type 2 diabetic rats, indicating that HOMA- $\beta$ in the PTF group was higher than that in the diabetes model group $(\mathrm{P}<0.01)$. The results provide convincing evidence for PTF regulation of PA-induced insulin secretion in INS-1 cells.

PTF enhances the protein expression of GPR40 reduced by $P A$ in INS-1 cells. GPR40 is a membrane-bound receptor for
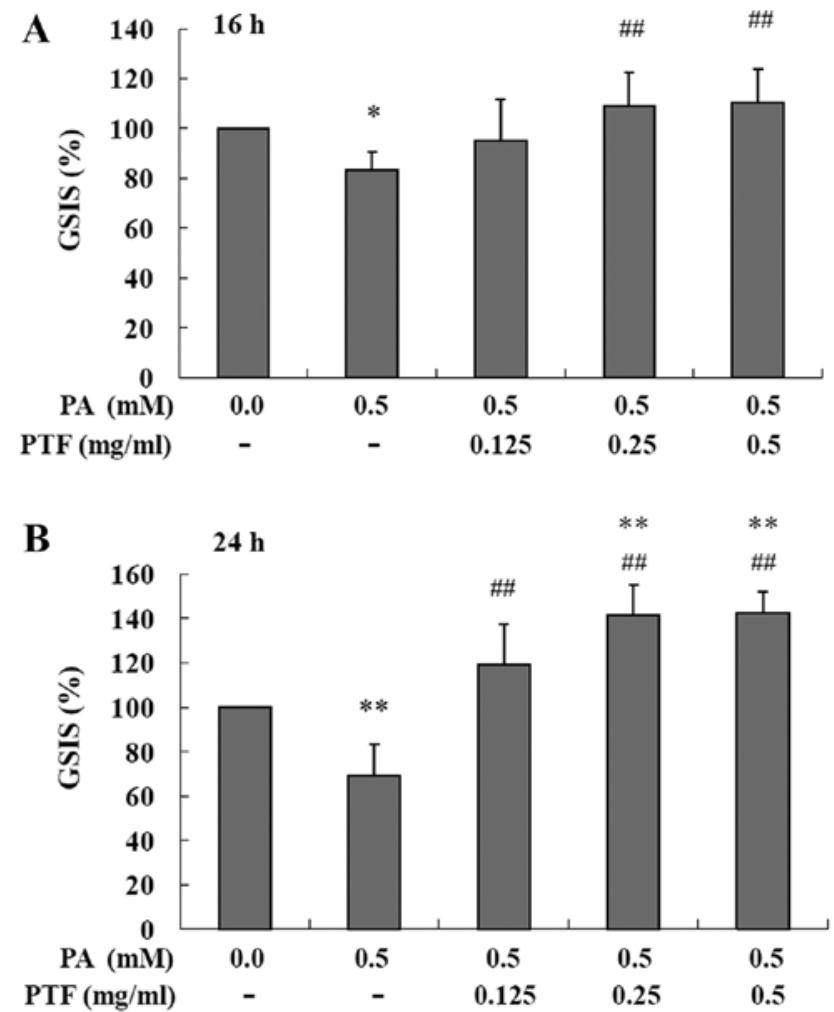

Figure 2. Effects of Pollen Typhae total flavone (PTF) on palmitic acid (PA)-induced impairment of GSIS in INS-1 cells. After treatment with PA in the presence or absence of PTF for $16 \mathrm{~h}$ (A) and $24 \mathrm{~h}$ (B), respectively, the cells were stimulated with $16.7 \mathrm{mM}$ glucose, and insulin secretion was determined as described in Materials and methods. ${ }^{*} \mathrm{P}<0.05$ and ${ }^{* *} \mathrm{P}<0.01$ vs. the control ( $0.0 \mathrm{mM} \mathrm{PA}) ;{ }^{\# \#} \mathrm{P}<0.01$ vs. $0.5 \mathrm{mM}$ PA. $\mathrm{n}=4-5$.

medium- and long-chain FFAs. Acute FFA exposure promotes GSIS through GPR40, but chronic elevated FFAs lead to a reduction in GPR40 expression with decreased GSIS $(5,11)$. In this study, PA exposure to INS-1 cells for $24 \mathrm{~h}$ decreased the protein expression of GPR40 $(\mathrm{P}<0.01)$ (Fig. 5) as compared to the control (0.0 mM PA), implying that PA impaired GSIS involving GPR40 and the subsequent cascade reaction in INS-1 cells. Administration of PTF inhibited the reduction of GPR40 protein expression $(\mathrm{P}<0.05)$.

Effects of PTF on the protein expression and the activity of PLC induced by PA in INS-1 cells. GW9508, a selective GPR40 agonist, binds GPR40 and subsequently activates the $\beta$ subtype of PLC, which promotes phosphatidylinositol4,5-bisphosphate (PIP2) to produce the second messenger molecules IP3 and DAG, thus potentiating GSIS in pancreatic $\beta$ cells $(22,23)$. IP3 can be transformed into IP2 and IP1. PA exposure for $24 \mathrm{~h}$ significantly decreased the protein expression of PLC $\beta 1$ and PLC $\beta 3$ ( $\mathrm{P}<0.05$ or $\mathrm{P}<0.01)$ (Fig. 6A) when compared to the control (0.0 mM PA), while PTF treatment did not inhibit the reduction in the protein expression in the INS-1 cells. Moreover, PA incubation for $24 \mathrm{~h}$ reduced IP3 (Fig. 6B) and DAG levels (Fig. 6C), and PTF significantly increased IP3 $(\mathrm{P}<0.01)$ and DAG levels $(\mathrm{P}<0.01)$ induced by PA in the INS-1 cells when compared to the control or $0.5 \mathrm{mM}$ PA, which were blocked by U-73122, an inhibitor of PLC. Additionally, GW9508 exposure to INS-1 cells for $60 \mathrm{~min}$ acutely increased IP1 levels $(\mathrm{P}<0.01)$ (Fig. 6D), and PA preincubation for 

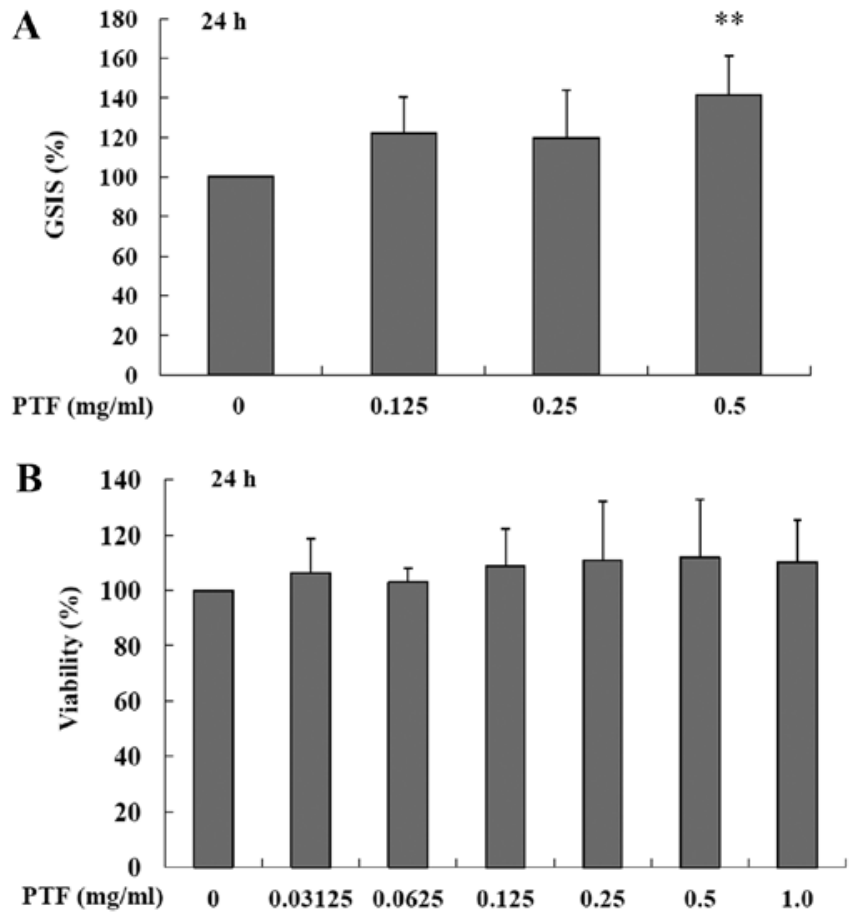

Figure 3. Effects of Pollen Typhae total flavone (PTF) on glucose-stimulated insulin secretion (GSIS) and the viability of INS-1 cells. (A) After treatment with PTF for $24 \mathrm{~h}$, the cells were stimulated with $16.7 \mathrm{mM}$ glucose, and insulin secretion was determined as described in Materials and methods. (B) After treatment with PTF for $24 \mathrm{~h}$, the viability of INS-1 cells was analyzed by XTT assay. ${ }^{* *} \mathrm{P}<0.01$ vs. the control $(0 \mathrm{mg} / \mathrm{ml}$ PTF $) . \mathrm{n}=4-5$.

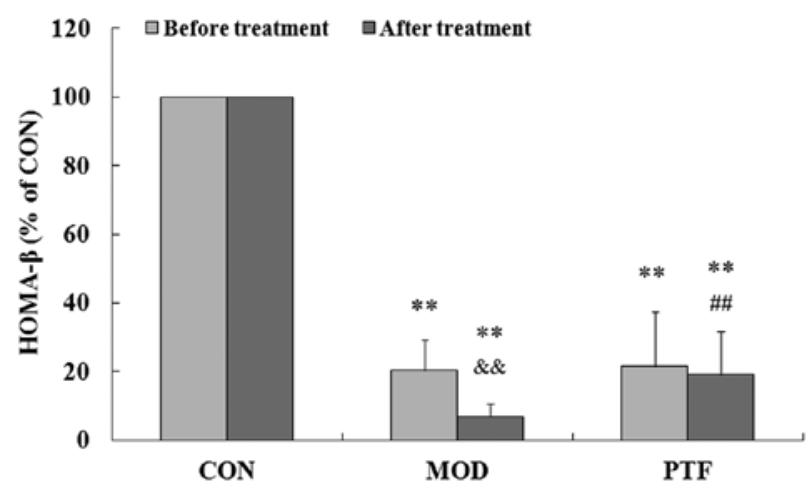

Figure 4. Effect of Pollen Typhae total flavone (PTF) on homeostasis model assessment of $\beta$ cell function (HOMA- $\beta$ ) in type 2 diabetic rats. Type 2 diabetes in rats was induced by high-fat diet and low-dose streptozotocin (STZ). Before and after PTF treatment for 4 weeks, insulin secretion function of pancreatic $\beta$ cells was evaluated by homeostasis model assessment of $\beta$ cell function (HOMA- $\beta$ ). ${ }^{* *} \mathrm{P}<0.01$ vs. the control group ( $\mathrm{CON}$, non-diabetic rats); ${ }^{\# \#} \mathrm{P}<0.01$ vs. the diabetes model group $(\mathrm{MOD}) ;{ }^{\&}{ }^{\&} \mathrm{P}<0.01$ vs. before treatment. PTF, PTF group. $n=8$.

24 h significantly decreased GW9508-stimulated IP1 levels $(\mathrm{P}<0.01)$, which was similar to U-73122, suggesting decreased activity of PLC induced by PA. Notably, PTF markedly prevented this reduction $(\mathrm{P}<0.01)$, which was also inhibited by U-73122. Together, PTF promotes GW9508-stimulated activity of PLC induced by PA in INS-1 cells.

Effects of PTF on PKC protein expression and activity induced by PA in INS-1 cells. As shown in Fig. 7, compared

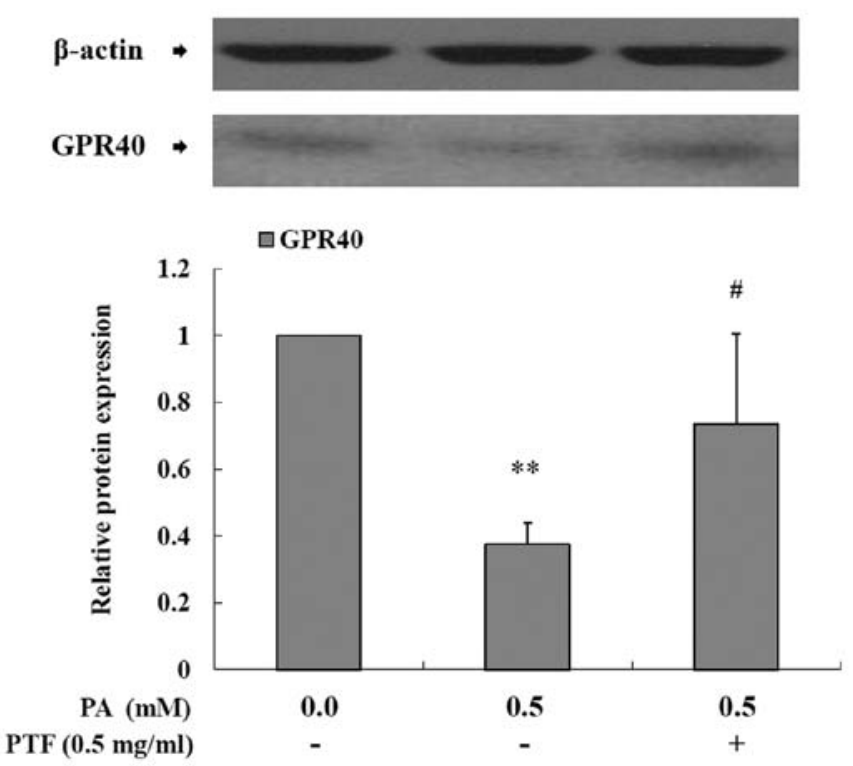

Figure 5. Effect of Pollen Typhae total flavone (PTF) on the protein expression of G-protein-coupled receptor 40 (GPR40) reduced by palmitic acid (PA) in INS-1 cells. After treatment for $24 \mathrm{~h}$, GPR40 protein expression was determined by western blotting as described in Materials and methods. ${ }^{* *} \mathrm{P}<0.01$ vs. the control $(0.0 \mathrm{mM} \mathrm{PA}) ;{ }^{\#} \mathrm{P}<0.05$ vs. $0.5 \mathrm{mM}$ PA.

with the control (0.0 mM PA), PA significantly reduced the protein expression of PKC $(\mathrm{P}<0.05)$ (Fig. 7A), and PTF to a certain extent strengthened the protein expression reduced by PA in INS-1 cells. Moreover, acute GW9508 exposure markedly increased the activity of PKC $(\mathrm{P}<0.01)$ (Fig. 7B), but PA pretreatment for $24 \mathrm{~h}$ led to a significant reduction $(\mathrm{P}<0.01)$ in the activity of PKC stimulated by GW9508 in the INS-1 cells, which was similar to STA, a specific inhibitor of PKC. Moreover, PTF intervention prevented the reduction $(\mathrm{P}<0.01)$, which was inhibited by STA.

Preventive effect of PTF on PA-induced impairment of GSIS is abolished by several inhibitors in INS-1 cells. In line with the above state, PA reduced GSIS in the INS-1 cells, which was prevented by PTF. The preventive effect of PTF was abolished by U-73122, STA and NIF, respectively (all $\mathrm{P}<0.01)$ (Fig. 8), known as PLC inhibitor, PKC inhibitor, and calcium antagonist, respectively. The results imply that PTF prevents PA-induced impairment of GSIS involving GPR40 signaling.

\section{Discussion}

In addition to providing an important energy source, FFAs, such as saturated fatty acid PA and unsaturated fatty acid oleic acid (OA), also play a key role in mediating insulin secretion of pancreatic $\beta$ cells. Studies have shown that acute FFA exposure increases insulin output in pancreatic $\beta$ cells $(5,24)$, whereas chronic elevated FFAs reduce GSIS $(8,25)$. In the present study, PA exposure to INS-1 cells severely impaired cell viability. Although PA did not affect the basic insulin secretion, PA significantly reduced GSIS in a time-dependent manner, which was compatible with previous reports $(8,25)$. In addition, administration of PTF prevented PA-induced impairment of GSIS in a dose-dependent manner, and potentiated 

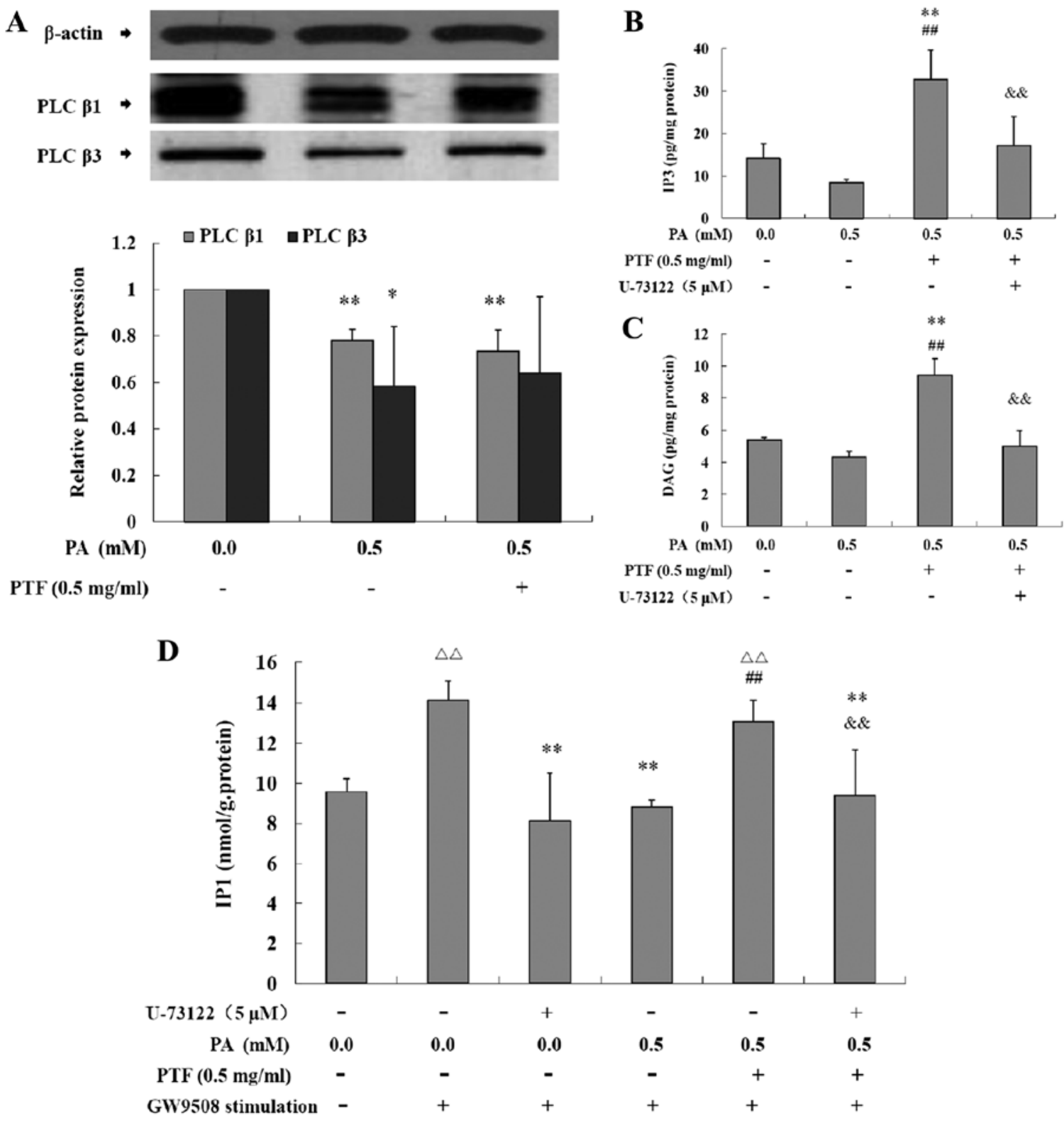

Figure 6. Effects of Pollen Typhae total flavone (PTF) on the protein expression and the activity of phospholipase C (PLC) reduced by palmitic acid (PA) in INS-1 cells. (A) After treatment for $24 \mathrm{~h}$, the protein expression levels of PLC $\beta 1$ and PLC $\beta 3$ were determined by western blotting. ${ }^{*} \mathrm{P}<0.05$ and ${ }^{* * *} \mathrm{P}<0.01 \mathrm{vs}$. the control (0.0 mM PA). (B and C) After treatment for $24 \mathrm{~h}$, the cells were incubated with KRB containing $2.5 \mathrm{mM}$ glucose for $1 \mathrm{~h}$ followed by treatment with $16.7 \mathrm{mM}$ glucose for $5 \mathrm{~min}$. Triphosphoinositide (IP3) (B) and diacylglycerol (DAG) (C) levels were assessed as described in Materials and methods. ${ }^{* *} \mathrm{P}<0.01$ vs. the control $(0.0 \mathrm{mM} \mathrm{PA}) ;{ }^{\# \#} \mathrm{P}<0.01$ vs. $0.5 \mathrm{mM} \mathrm{PA}$; ${ }^{\& \&} \mathrm{P}<0.01$ vs. $0.5 \mathrm{mM} \mathrm{PA}+0.5 \mathrm{mg} / \mathrm{ml} \mathrm{PTF}$. (D) After treatment for $24 \mathrm{~h}$, the cells were stimulated with or without GW9508 $(20 \mu \mathrm{M})$ for $60 \mathrm{~min}$, and PLC activity was analyzed as described in Materials and methods. ${ }^{\triangle 4} \mathrm{P}<0.01 \mathrm{vs} .0 .0 \mathrm{mM} \mathrm{PA} ;{ }^{* * *} \mathrm{P}<0.01 \mathrm{vs} .0 .0 \mathrm{mM}$ PA+GW9508 stimulation; " $\mathrm{P}<0.01$ vs. $0.5 \mathrm{mM}$ PA+GW9508 stimulation; \&\& $\mathrm{P}<0.01$ vs. $0.5 \mathrm{mM} \mathrm{PA}+0.5 \mathrm{mg} / \mathrm{ml} \mathrm{PTF}+\mathrm{GW} 9508$ stimulation.

GSIS in INS-1 cells. Moreover, PTF ameliorated the insulin secretion function in HFD and low-dose STZ-induced type 2 diabetic rats. It is generally accepted that insulin secretion dysfunction is a hallmark of type 2 diabetes. Moreover, dyslipidaemia is a characteristic of type 2 diabetes, and continuous elevated blood lipids contribute to insulin secretion dysfunction, thus exacerbating type 2 diabetes (26). We previously reported that PTF reduces triglyceride (TG) and low-density lipoprotein cholesterol (LDL-c), decreases blood glucose, and improves insulin resistance in diabetic rats (17). Together, these results indicate the protective action of PTF against PA-induced impairment of GSIS in INS-1 cells, suggesting the anti-diabetic action of PTF.
GPR40, known as free fatty acid receptor 1 (FFAR1), is a cellsurface receptor and is predominantly expressed in pancreatic $\beta$ cells. GPR40 has a high affinity with endogenous mediumand long-chain fatty acids including PA and OA. Activated GPR40 by FFAs or agonist amplifies GSIS from pancreatic $\beta$ cells $(24,27,28)$. In fact, GPR40 expression is decreased in type 2 diabetic islets with reduced GSIS $(11,29)$, and GPR40 knockout impairs GSIS in mice $(30,31)$. On the contrary, overexpression of GPR40 potentiates GSIS and ameliorates glucose tolerance in normal and diabetic mice (32). Therefore, GPR40 is a potential therapeutic target for the development of antidiabetic drugs $(33,34)$. In this study, elevated PA exposure for $24 \mathrm{~h}$ led to a significant reduction in GPR40 protein expression 
A
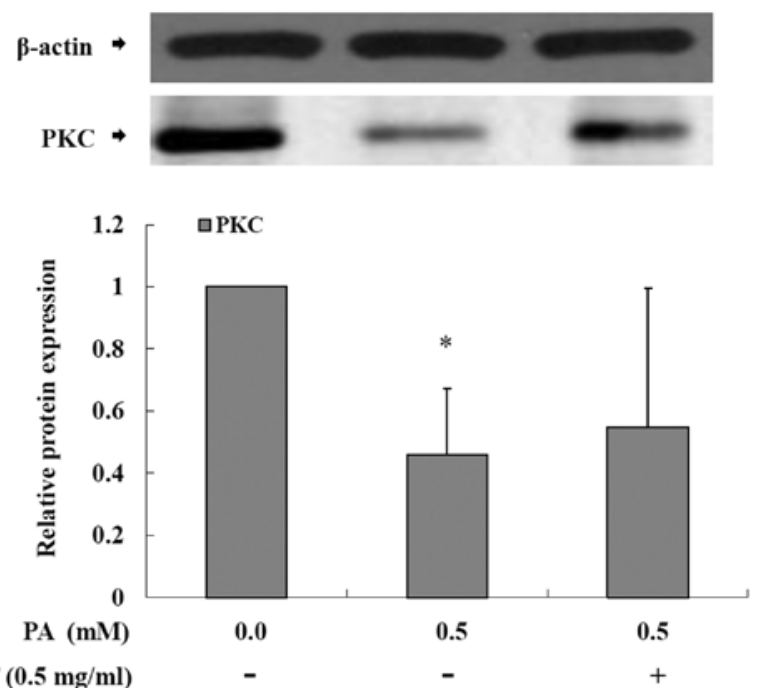

PTF $(0.5 \mathrm{mg} / \mathrm{ml})$

B

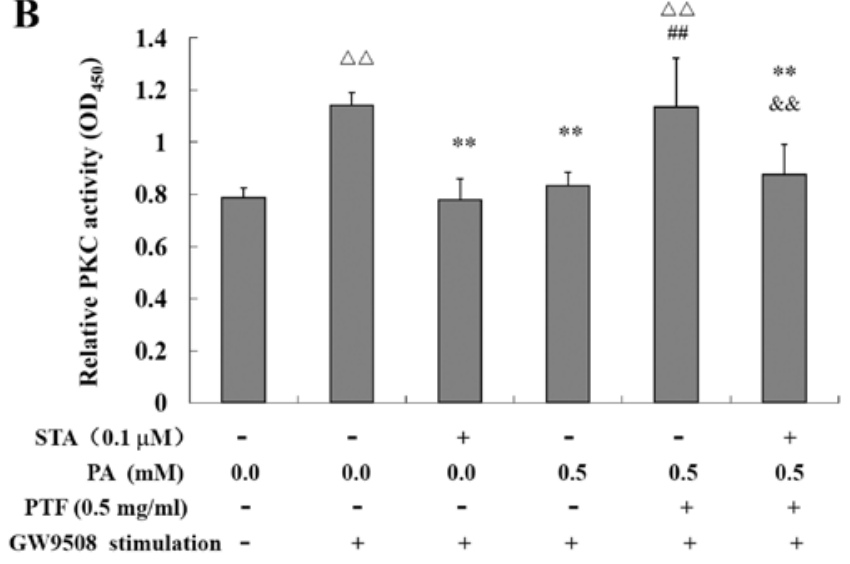

Figure 7. Effects of Pollen Typhae total flavone (PTF) on the protein expression and the activity of protein kinase $\mathrm{C}(\mathrm{PKC})$ induced by palmitic acid (PA) in INS-1 cells. (A) After treatment for $24 \mathrm{~h}$, the protein expression of $\mathrm{PKC}$ was analyzed by western blotting. " $\mathrm{P}<0.05$ vs. the control $(0.0 \mathrm{mM}$ PA). (B) After treatment for $24 \mathrm{~h}$, the cells were stimulated with or without GW9508 $(20 \mu \mathrm{M})$ for $60 \mathrm{~min}$, and the activity of PKC was determined as described in Materials and methods. ${ }^{\triangle} \mathrm{P}<0.01$ vs. $0.0 \mathrm{mM} \mathrm{PA} ;{ }^{* *} \mathrm{P}<0.01$ vs. $0.0 \mathrm{mM}$ PA+GW9508 stimulation; ${ }^{\# \#} \mathrm{P}<0.01$ vs. $0.5 \mathrm{mM}$ PA+GW9508 stimulation; ${ }^{\& \&} \mathrm{P}<0.01$ vs. $0.5 \mathrm{mM} \mathrm{PA}+0.5 \mathrm{mg} / \mathrm{ml} \mathrm{PTF}+\mathrm{GW} 9508$ stimulation.

in INS-1 cells. Del Guerra et al also reported that increased FFA preexposure for $24 \mathrm{~h}$ significantly decreased GPR $40 \mathrm{mRNA}$ in islets from multiorgan donors (11), consistent with this study, implying that chronic elevated FFAs result in a reduction in GPR40 involving impaired GSIS. In addition, PTF treatment prevented GPR40 reduction induced by PA. Additionally, similar to the above state, PTF ameliorates insulin resistance in type 2 diabetic rats (17) in addition to augmenting GSIS in INS-1 cells and improving insulin secretion function in type 2 diabetic rats, which is similar to rosiglitazone, a peroxisome proliferator-activated receptor (PPAR) $\gamma$ agonist functioning to improve insulin resistance. Rosiglitazone has been reported to upregulate GPR40 expression and promote insulin secretion in pancreatic islets $(29,35)$, which was blocked by a PLC inhibitor (35). The data suggest that PTF prevented PA-induced impairment of GSIS involving GPR40 signaling in INS-1 cells.

Upon stimulation, GPR 40 activates the $\beta$ subtype of PLC, which catalyzes PIP2 to produce IP3 and DAG. Increased IP3

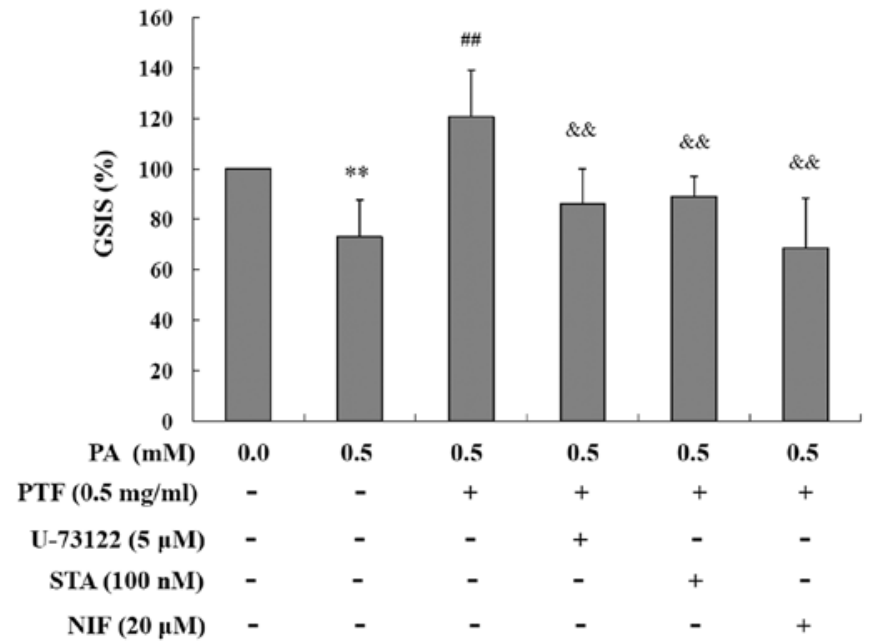

Figure 8. Several inhibitors abolish the preventive effect of Pollen Typhae total flavone (PTF) on palmitic acid (PA)-induced impairment of glucose-stimulated insulin secretion (GSIS) in INS-1 cells. After treatment for $24 \mathrm{~h}$, the cells were stimulated with $16.7 \mathrm{mM}$ glucose, and insulin secretion was assessed as described in the Materials and methods. U-73122, phospholipase C (PLC) inhibitor; STA, staurosporine - protein kinase C (PKC) inhibitor; NIF, nifedipine - calcium antagonist. ${ }^{* *} \mathrm{P}<0.01$ vs. the control (0.0 mM PA); ${ }^{\# \#} \mathrm{P}<0.01$ vs. $0.5 \mathrm{mM}$ PA; ${ }^{\&} \mathrm{P}<0.01$ vs. $0.5 \mathrm{mM}$ PA+0.5 mg/ml PTF. $\mathrm{n}=5$.

transfers to the ER and promotes the release of stored $\mathrm{Ca}^{2+}$, and elevated cytoplasmic $\mathrm{Ca}^{2+}$ levels augment GSIS $(24,34)$. In addition, DAG activates PKC and then amplifies GSIS $(34,36)$. The acute promotion of GSIS by FFAs is dependent on GPR40 signaling, which is attenuated by GPR40 knockout, PLC or L-type $\mathrm{Ca}^{2+}$ channel inhibitor $(24,30,37)$. Activated GPR40 by fasiglifam (TAK-875) was also found to promote the activation of GPR40 substrate cascade signal transduction, thus augmenting GSIS $(38,39)$. Contrary to the acute effects of FFAs, chronic FFA exposure to islets decreases GPR40 mRNA expression and GSIS (11), implying impairment of the GPR40 signaling pathway. To further reveal the mechanisms, we observed the effects of PTF on GPR40 signaling induced by PA in INS-1 cells. In the present study, PA exposure for $24 \mathrm{~h}$ significantly decreased the protein expression of PLC $\beta 1$, PLC 33 and PKC in the INS-1 cells; moreover, PA reduced intracellular IP3 and DAG levels, and markedly inhibited GW9508-stimulated activity of PLC and PKC. Acute exposure to GW9508, a GPR40 agonist, increased the activity of GPR40 signaling in INS-1 cells, indicating elevated activity of PLC and PKC, which were inhibited by PLC and PKC inhibitors, respectively. Interestingly, this inhibition was similar to PA. Studies have reported that GW9508 amplifies GSIS involving PKC activation (23), and that TAK-875 enhances GSIS through IP3-mediated $\mathrm{Ca}^{2+}$ release and DAG/PKC mechanisms (38), which were consistent with the findings of the present study. The data revealed that elevated PA caused inactivation of the GPR40 pathway in INS-1 cells. Although PTF did not obviously change the protein expression of PLC $\beta 1$, PLC $\beta 3$ or PKC, PTF significantly increased intracellular IP3 and DAG levels, and potentiated GW9508-stimulated activity of PLC and PKC induced by PA in the INS- 1 cells, which were similar to GW9508 and blocked by PLC and PKC inhibitors, respectively. Furthermore, the preventive effect of PTF on PA-induced impairment of GSIS was abolished by PLC 
and PKC inhibitors, and calcium antagonist, respectively. Glucagon-like peptide-1 (GLP-1), an endogenous glucoselowering hormone, also stimulates insulin secretion through the PLC/PKC-dependent pathway in isolated islets (40). The extract from Corydalis edulis Maxim., a widely grown plant in China, was found to enhance insulin secretion by the activation of PKC in pancreatic $\beta$ cells (41). The results provide evidence for the protective role of PTF against PA-induced impairment of GSIS involving GPR40 signaling in INS-1 cells.

In addition to the beneficial effects of PTF on GPR40 signaling in vitro, PTF was found to decrease TG and LDL-c in type 2 diabetic rats (17). This study showed that PTF improved insulin secretion function in type 2 diabetic rats. Type 2 diabetes often coexists with dyslipidemia; it is likely that PTF reduces plasma FFA levels in vivo, thus decreasing the negative influence of FFAs on pancreatic $\beta$ cells and improving insulin secretion. Furthermore, chronic elevated FFAs accumulate in pancreatic $\beta$ cells, thereby leading to pancreatic lipotoxicity. Chronic exposure to high FFAs triggers oxidative stress $(42,43)$, inflammatory response $(6,44)$, and apoptosis $(45,46)$, and inhibits preproinsulin gene expression (10), thus impairing pancreatic $\beta$ cell function. Lou et al reported that PTF inhibits IL-6 mRNA expression and IL-6 secretion via the NF- $\kappa \mathrm{B}$ pathway in PA-induced $\mathrm{C} 2 \mathrm{C} 12$ skeletal muscle cells (47). We propose that PTF may ameliorate pancreatic lipotoxicity through inhibition of lipid accumulation and inflammation, and subsequently protects insulin secretion of pancreatic $\beta$ cells, which warrants further research.

We previously reported that PTF contains typhaneoside and other components (16). Moreover, Pollen Typhae extract was further determined to contain several flavonoids including typhaneoside, isorhamnetin, naringenin, kaempferol, quercetin and isorhamnetin-3-O-neohesperidoside $(12,13,48)$. Studies indicate that naringenin and quercetin enhance GSIS in INS-1E cells (49), while kaempferol improves the impairment of GSIS induced by palmitate in INS-1E cells and human islets (50), which are in line with the findings of the present study. Further studies revealed that naringenin and quercetin promote the gene expression of glucose transporter-2 (GLUT-2), glucokinase (GCK), INS-1, and duodenal homeobox-1 (PDX-1), which involve an increase in insulin secretion, and that naringenin enhances the Bcl-2 mRNA level and reduces the caspase-3 mRNA level, whereas quercetin promotes the Bcl-2 mRNA level, thereby inhibiting $\beta$ cell apoptosis (49). Additionally, naringenin inhibits the activity of dipeptidyl peptidase IV (DPP-IV) (51), which plays a role in insulin secretion. Quercetin increased $\mathrm{Ca}^{2+}$ influx by activating L-type $\mathrm{Ca}^{2+}$ channels, thus inducing insulin secretion, which were nearly abolished by the $\mathrm{Ca}^{2+}$ channel antagonist nifedipine (52). Similarly, the improvement in PA-induced impairment of GSIS by PTF was also blocked by nifedipine in this study. Moreover, kaempferol was found to protect INS-1E cells and human islets against palmitate-induced apoptosis and improve palmitate-induced dysfunction via upregulation of the PDX-1/cAMP/PKA/CREB signaling cascade (50). It was confirmed that increased FFAs induce oxidative stress to impair GSIS in pancreatic islets $(42,43)$, and typhaneoside and isorhamnetin-3-O-neohesperidoside have antioxidant capacity against lipopolysaccharide in human umbilical vein endothelial cells (12). These two compounds may mediate insulin secretion in pancreatic $\beta$ cells. Therefore, it is necessary to ascertain whether other flavonoids including typhaneoside and isorham-
netin-3-O-neohesperidoside can regulate insulin secretion and to reveal the underlying mechanisms.

In conclusion, the present study demonstrated that PTF exerts a protective role against PA-induced impairment of GSIS involving GPR40 signaling in INS-1 cells. The study provides evidence for the treatment of type 2 diabetes using Pollen Typhae in clinical practice.

\section{Acknowledgements}

The present study was supported by the National Natural Science Foundation of China (no. 81202677) and the Guangxi Key Laboratory of Chinese Medicine Foundation Research (no. 15-140-32-05), Guangxi University of Chinese Medicine.

\section{References}

1. Chan JC, Malik V, Jia W, Kadowaki T, Yajnik CS, Yoon KH and Hu FB: Diabetes in Asia: Epidemiology, risk factors, and pathophysiology. JAMA 301: 2129-2140, 2009.

2. Liang H, Tantiwong P, Sriwijitkamol A, Shanmugasundaram K, Mohan S, Espinoza S, Defronzo RA, Dubé JJ and Musi N: Effect of a sustained reduction in plasma free fatty acid concentration on insulin signalling and inflammation in skeletal muscle from human subjects. J Physiol 591: 2897-2909, 2013.

3. Daniele G, Eldor R, Merovci A, Clarke GD, Xiong J, Tripathy D, Taranova A, Abdul-Ghani M and DeFronzo RA: Chronic reduction of plasma free fatty acid improves mitochondrial function and whole-body insulin sensitivity in obese and type 2 diabetic individuals. Diabetes 63: 2812-2820, 2014.

4. Belfort R, Mandarino L, Kashyap S, Wirfel K, Pratipanawatr T, Berria R, Defronzo RA and Cusi K: Dose-response effect of elevated plasma free fatty acid on insulin signaling. Diabetes 54: 1640-1648, 2005.

5. Ayvaz G, Balos Törüner F, Karakoç A, Yetkin I, Cakir N and Arslan M: Acute and chronic effects of different concentrations of free fatty acids on the insulin secreting function of islets. Diabetes Metab 28: 3S7-3S112, 2002.

6. Eguchi K, Manabe I, Oishi-Tanaka Y, Ohsugi M, Kono N, Ogata F, Yagi N, Ohto U, Kimoto M, Miyake K, et al: Saturated fatty acid and TLR signaling link $\beta$ cell dysfunction and islet inflammation. Cell Metab 15: 518-533, 2012.

7. Kharroubi I, Ladrière L, Cardozo AK, Dogusan Z, Cnop M and Eizirik DL: Free fatty acids and cytokines induce pancreatic beta-cell apoptosis by different mechanisms: Role of nuclear factor-kappaB and endoplasmic reticulum stress. Endocrinology 145: 5087-5096, 2004.

8. Yang Y, Tong Y, Gong M, Lu Y, Wang C, Zhou M, Yang Q, Mao T and Tong N: Activation of PPAR $\beta / \delta$ protects pancreatic $\beta$ cells from palmitate-induced apoptosis by upregulating the expression of GLP-1 receptor. Cell Signal 26: 268-278, 2014.

9. Sun Y, Ren M, Gao GQ, Gong B, Xin W, Guo H, Zhang XJ, Gao L and Zhao JJ: Chronic palmitate exposure inhibits AMPKalpha and decreases glucose-stimulated insulin secretion from beta-cells: Modulation by fenofibrate. Acta Pharmacol Sin 29: 443-450, 2008.

10. Ritz-Laser B, Meda P, Constant I, Klages N, Charollais A, Morales A, Magnan C, Ktorza A and Philippe J: Glucose-induced preproinsulin gene expression is inhibited by the free fatty acid palmitate. Endocrinology 140: 4005-4014, 1999.

11. Del Guerra S, Bugliani M, D'Aleo V, Del Prato S, Boggi U, Mosca F, Filipponi F and Lupi R: G-protein-coupled receptor 40 (GPR40) expression and its regulation in human pancreatic islets: The role of type 2 diabetes and fatty acids. Nutr Metab Cardiovasc Dis 20: 22-25, 2010.

12. Chen P, Cao Y, Bao B, Zhang L and Ding A: Antioxidant capacity of Typha angustifolia extracts and two active flavonoids. Pharm Biol 55: 1283-1288, 2017.

13. Cao S, Ni B, Feng L, Yin X, Dou H, Fu J, Lin L and Ni J: Simultaneous determination of typhaneoside and isorhamnetin3-O-neohesperidoside in rats after oral administration of Pollen Typhae extract by UPLC-MS/MS. J Chromatogr Sci 53: 866-871, 2015. 
14. Ohkura N, Tamura K, Tanaka A, Matsuda J and Atsumi G: Experimental study on the hemostatc activity of Pollen Typhae: A traditional folk medicine used by external and oral application. Blood Coagul Fibrinolysis 22: 631-636, 2011.

15. Zhao J, Zhang CY, Xu DM, Huang GQ, Xu YL, Wang ZY, Fang SD, Chen Y and Gu YL: The antiatherogenic effects of components isolated from pollen typhae. Thromb Res 57: 957-966, 1990.

16. Feng XT, Wang TZ, Chen Y, Liu JB, Liu Y and Wang WJ: Pollen Typhae total flavone improves insulin-induced glucose uptake through the $\beta$-arrestin-2-mediated signaling in $\mathrm{C} 2 \mathrm{C} 12$ myotubes. Int J Mol Med 30: 914-922, 2012.

17. Feng XT, Chen Q, Xie Z, Liang X, Jiang ZH, Zhao W and Leng J: Pollen Typhae total flavone improves insulin resistance in high-fat diet and low-dose streptozotocin-induced type 2 diabetic rats. Biosci Biotechnol Biochem 78: 1738-1742, 2014.

18. Feng XT, Wang TZ, Leng J, Chen Y, Liu JB, Liu Y and Wang WJ: Palmitate contributes to insulin resistance through downregulation of the Src-mediated phosphorylation of Akt in $\mathrm{C} 2 \mathrm{C} 12$ myotubes. Biosci Biotechnol Biochem 76: 1356-1361, 2012.

19. Feng XT, Zhai LN, Wang CL, Zhao W, Chen Q and Huang XQ: Effects of Pollen Typhae total flavone on $\beta$-arrestin-2/Src/Akt signaling in adipose tissues of type 2 diabetic rats. Afr J Tradit Complement Altern Med 12: 74-78, 2015.

20. Borg J, Klint C, Wierup N, Ström K, Larsson S, Sundler F, Lupi R, Marchetti P, Xu G, Kimmel A, et al: Perilipin is present in islets of Langerhans and protects against lipotoxicity when overexpressed in the beta-cell line INS-1. Endocrinology 150 3049-3057, 2009.

21. Bas AL, Demirci S, Yazihan N, Uney K and Ermis Kaya E: Nerium oleander distillate improves fat and glucose metabolism in high-fat diet-fed streptozotocin-induced diabetic rats. Int J Endocrinol 2012: 947187, 2012.

22. Yaluri N, Modi S, López Rodríguez M, Stančáková A, Kuusisto J, Kokkola T and Laakso M: Simvastatin impairs insulin secretion by multiple mechanisms in MIN6 cells. PLoS One 10: e0142902, 2015.

23. Graciano MF, Valle MM, Curi R and Carpinelli AR: Evidence for the involvement of GPR40 and NADPH oxidase in palmitic acid-induced superoxide production and insulin secretion. Islets 5: 139-148, 2013.

24. Fujiwara K, Maekawa F and Yada T: Oleic acid interacts with GPR40 to induce $\mathrm{Ca}^{2+}$ signaling in rat islet beta-cells: Mediation by PLC and L-type $\mathrm{Ca}^{2+}$ channel and link to insulin release. Am J Physiol Endocrinol Metab 289: E670-E677, 2005.

25. Barlow J, Jensen VH, Jastroch M and Affourtit C: Palmitateinduced impairment of glucose-stimulated insulin secretion precedes mitochondrial dysfunction in mouse pancreatic islets. Biochem J 473: 487-496, 2016.

26. Zheng S, Zhou H, Han T, Li Y, Zhang Y, Liu W and Hu Y: Clinical characteristics and beta cell function in Chinese patients with newly diagnosed type 2 diabetes mellitus with different levels of serum triglyceride. BMC Endocr Disord 15: 21, 2015.

27. Kristinsson H, Smith DM, Bergsten P and Sargsyan E: FFAR1 is involved in both the acute and chronic effects of palmitate on insulin secretion. Endocrinology 154: 4078-4088, 2013.

28. Yashiro H, Tsujihata Y, Takeuchi K, Hazama M, Johnson PR and Rorsman P: The effects of TAK-875, a selective G proteincoupled receptor 40/free fatty acid 1 agonist, on insulin and glucagon secretion in isolated rat and human islets. $\mathrm{J}$ Pharmacol Exp Ther 340: 483-489, 2012.

29. Meidute Abaraviciene S, Muhammed SJ, Amisten S, Lundquist I and Salehi A: GPR40 protein levels are crucial to the regulation of stimulated hormone secretion in pancreatic islets. Lessons from spontaneous obesity-prone and non-obese type 2 diabetes in rats. Mol Cell Endocrinol 381: 150-159, 2013.

30. Alquier T, Peyot ML, Latour MG, Kebede M, Sorensen CM, Gesta S, Ronald Kahn C, Smith RD, Jetton TL, Metz TO, et al: Deletion of GPR40 impairs glucose-induced insulin secretion in vivo in mice without affecting intracellular fuel metabolism in islets. Diabetes 58: 2607-2615, 2009.

31. Ferdaoussi M, Bergeron V, Zarrouki B, Kolic J, Cantley J, Fielitz J, Olson EN, Prentki M, Biden T, MacDonald PE, et al: G protein-coupled receptor (GPR)40-dependent potentiation of insulin secretion in mouse islets is mediated by protein kinase D1. Diabetologia 55: 2682-2692, 2012.

32. Nagasumi K, Esaki R, Iwachidow K, Yasuhara Y, Ogi K, Tanaka H, Nakata M, Yano T, Shimakawa K, Taketomi S, et al: Overexpression of GPR40 in pancreatic $\beta$-cells augments glucosestimulated insulin secretion and improves glucose tolerance in normal and diabetic mice. Diabetes 58: 1067-1076, 2009.
33. Chen $\mathrm{C}$, Li $\mathrm{H}$ and Long YQ: GPR40 agonists for the treatment of type 2 diabetes mellitus: The biological characteristics and the chemical space. Bioorg Med Chem Lett 26: 5603-5612, 2016.

34. Feng XT, Leng J, Xie Z, Li SL, Zhao W and Tang QL: GPR40: A therapeutic target for mediating insulin secretion (Review). Int J Mol Med 30: 1261-1266, 2012.

35. Kim HS, Hwang YC, Koo SH, Park KS, Lee MS, Kim KW and Lee MK: PPAR- $\gamma$ activation increases insulin secretion through the up-regulation of the free fatty acid receptor GPR40 in pancreatic $\beta$-cells. PLoS One 8: e50128, 2013.

36. Straub SG and Sharp GW: Massive augmentation of stimulated insulin secretion induced by fatty acid-free BSA in rat pancreatic islets. Diabetes 53: 3152-3158, 2004.

37. Schnell S, Schaefer M and Schöfl C: Free fatty acids increase cytosolic free calcium and stimulate insulin secretion from betacells through activation of GPR40. Mol Cell Endocrinol 263: 173-180, 2007.

38. Sakuma K, Yabuki C, Maruyama M, Abiru A, Komatsu H, Negoro N, Tsujihata Y, Takeuchi K, Habata Y and Mori M: Fasiglifam (TAK-875) has dual potentiating mechanisms via Gaq-GPR40/FFAR1 signaling branches on glucose-dependent insulin secretion. Pharmacol Res Perspect 4: e00237, 2016.

39. Yamada H, Yoshida M, Ito K, Dezaki K, Yada T, Ishikawa SE and Kakei M: Potentiation of glucose-stimulated insulin secretion by the GPR40-PLC-TRPC pathway in pancreatic $\beta$-cells. Sci Rep 6: 25912, 2016.

40. Shigeto M, Cha CY, Rorsman P and Kaku K: A role of PLC/PKC-dependent pathway in GLP-1-stimulated insulin secretion. J Mol Med (Berl) 95: 361-368, 2017.

41. Zheng J, Zhao Y, Lun Q, Song Y, Shi S, Gu X, Pan B, Qu C, Li J and Tu P: Corydalis edulis Maxim. promotes insulin secretion via the activation of protein kinase Cs (PKCs) in mice and pancreatic $\beta$ cells. Sci Rep 7: 40454, 2017.

42. Zhang X, Bao Y, Ke L and Yu Y: Elevated circulating free fatty acids levels causing pancreatic islet cell dysfunction through oxidative stress. J Endocrinol Invest 33: 388-394, 2010.

43. Piro S, Rabuazzo AM, Renis M and Purrello F: Effects of metformin on oxidative stress, adenine nucleotides balance, and glucose-induced insulin release impaired by chronic free fatty acids exposure in rat pancreatic islets. J Endocrinol Invest 35: 504-510, 2012.

44. Yin J, Peng Y, Wu J, Wang Y and Yao L: Toll-like receptor 2/4 links to free fatty acid-induced inflammation and $\beta$-cell dysfunction. J Leukoc Biol 95: 47-52, 2014.

45. Xiong X, Sun X, Wang Q, Qian X, Zhang Y, Pan X and Dong XC: SIRT6 protects against palmitate-induced pancreatic $\beta$-cell dysfunction and apoptosis. J Endocrinol 231: 159-165, 2016.

46. Litwak SA, Wali JA, Pappas EG, Saadi H, Stanley WJ, Varanasi LC, Kay TW, Thomas HE and Gurzov EN: Lipotoxic stress induces pancreatic $\beta$-cell apoptosis through modulation of Bcl-2 proteins by the ubiquitin-proteasome system. J Diabetes Res 2015: 280615, 2015 .

47. Lou SY, Liu Y, Chen WH, Ying J, He YM and Wang WJ: Pollen Typhae total flavones inhibit expression of interleukin- 6 in $\mathrm{C} 2 \mathrm{C} 12$ skeletal muscle cells cultured with palmitate. Zhong Xi Yi Jie He Xue Bao 6: 488-492, 2008 (In Chinese).

48. Yu XA, Azietaku JT, Li J, Cao J, An M, He J, Gao XM and Chang YX: Simultaneous determination of eight flavonoids in plasma using LC-MS/MS and application to a pharmacokinetic study after oral administration of Pollen Typhae extract to rats. J Chromatogr B Analyt Technol Biomed Life Sci 1044-1045: 158-165, 2017.

49. Bhattacharya S, Oksbjerg N, Young JF and Jeppesen PB: Caffeic acid, naringenin and quercetin enhance glucose-stimulated insulin secretion and glucose sensitivity in INS-1E cells. Diabetes Obes Metab 16: 602-612, 2014.

50. Zhang Y, Zhen W, Maechler P and Liu D: Small molecule kaempferol modulates PDX-1 protein expression and subsequently promotes pancreatic $\beta$-cell survival and function via CREB. J Nutr Biochem 24: 638-646, 2013.

51. Bower AM, Real Hernandez LM, Berhow MA and de Mejia EG: Bioactive compounds from culinary herbs inhibit a molecular target for type 2 diabetes management, dipeptidyl peptidase IV. J Agric Food Chem 62: 6147-6158, 2014.

52. Bardy G, Virsolvy A, Quignard JF, Ravier MA, Bertrand G, Dalle S, Cros G, Magous R, Richard S and Oiry C: Quercetin induces insulin secretion by direct activation of L-type calcium channels in pancreatic beta cells. Br J Pharmacol 169: 1102-1113, 2013. 